\title{
Glucagon-like peptide-1 regulates proliferation and apoptosis via activation of protein kinase B in pancreatic INS-1 beta cells
}

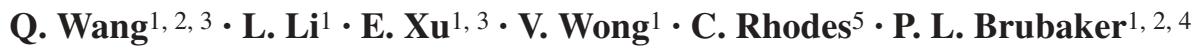 \\ ${ }^{1}$ Department of Physiology, University of Toronto, Toronto, Ontario, Canada \\ 2 Department of Medicine, Division of Endocrinology and Metabolism, University of Toronto, Toronto, Ontario, Canada \\ ${ }^{3}$ St Michael's Hospital, University of Toronto, Toronto, Ontario, Canada \\ ${ }^{4}$ Room 3366, Medical Sciences Building, University of Toronto, Toronto, Ontario, Canada \\ 5 Pacific Northwest Research Institute, Seattle, Washington, USA
}

\section{Abstract}

Aims/hypothesis. The incretin hormone glucagon-like peptide-1 augments islet cell mass in vivo by increasing proliferation and decreasing apoptosis of the beta cells. However, the signalling pathways that mediate these effects are mostly unknown. Using a clonal rat pancreatic beta cell line (INS-1), we examined the role of protein kinase B in mediating beta-cell growth and survival stimulated by glucagon-like peptide- 1 .

Methods. Immunoblot analysis was used to detect active (phospho-) and total protein kinase B. Proliferation was assessed using ${ }^{3} \mathrm{H}$-thymidine incorporation, while apoptosis was quantitated using 4'-6-diamidino2-phenylindole staining and APO percentage apoptosis assay. Kinase-dead and wild-type protein kinase B was introduced into cells using adenoviral vectors.

Results. Glucagon-like peptide-1 rapidly activated protein kinase B in INS-1 cells (by 2.7 \pm 0.7 -fold, $p<0.05$ ). This effect was completely abrogated by inhibition, with wortmannin, of the upstream activator of protein kinase B, phosphatidylinositol-3-kinase. Glucagon-like peptide- 1 also stimulated INS-1 cell proliferation in a dose-dependent manner (by $1.8 \pm 0.5$-fold at $10^{-7} \mathrm{~mol} / \mathrm{l}$, $p<0.01$ ), and inhibited staurosporine-induced apoptosis (by $69 \pm 12 \%, p<0.05$ ). Both of these effects were also prevented by wortmannin treatment. Ablation of protein kinase B by adenovirus-mediated overexpression of the kinase-dead form of protein kinase $\mathrm{B} \alpha$ prevented protein kinase $\mathrm{B}$ phosphorylation and completely abrogated both cellular proliferation $(p<0.05)$ and protection from drug-induced cellular death $(p<0.01)$ induced by glucagon-like peptide- 1 .

Conclusions/interpretation. These results identify protein kinase $\mathrm{B}$ as an essential mediator linking the glucagon-like peptide-1 signal to the intracellular machinery that modulates beta-cell growth and survival. [Diabetologia (2004) 47:478-487]

Keywords Glucagon-like peptide- 1 - Protein kinase B · Islet cell mass · Beta cell · growth · Proliferation · Apoptosis
Received: 25 September 2003 / Revised: 20 November 2003

Published online: 5 February 2004

C) Springer-Verlag 2004

\section{P. L. Brubaker ( $)$}

Room 3366, Medical Sciences Building,

University of Toronto, Toronto, Ontario, M5S 1A8, Canada

E-mail: p.brubaker@utoronto.ca

Abbreviations: AdV, adenovirus · DAPI, 4'-6-diamidino-2phenylindole · GFP, enhanced green fluorescent protein - GIP, glucose-dependent insulinotropic peptide - GLP, glucagon-like peptide - GPCR, G protein-coupled receptor - GSK3 $\alpha / \beta$, glycogen synthase kinase- $3 \alpha / \beta \cdot \mathrm{KD}$, kinase-dead $\cdot$ MAPK, mitogen-activated protein kinase $\cdot$ PI3-K, phosphatidylinositol-3kinase $\cdot$ PKB, protein kinase B $\cdot$ PTHrP, parathyroid hormone-related peptide $\cdot$ WT, wild-type

Q. Wang and L. Li contributed equally to this article
The incretin hormone glucagon-like peptide (GLP)-1 is a 30 -amino acid peptide secreted from the intestinal $\mathrm{L}$ cell in response to food ingestion [1, 2]. It possesses a variety of anti-diabetic actions that are mediated at the level of the beta cell, as well as in peripheral tissues. These include not only the stimulation of glucose-dependent insulin secretion $[3,4,5]$, but also the inhibition of glucagon release $[6,7]$, gastric emptying $[7,8]$ and food intake $[9,10]$, and possibly also enhancement of insulin sensitivity [11, 12]. Consistent with these biological actions, long-term treatment of Type 2 diabetic patients with GLP-1 decreases $\mathrm{HbA}_{1 \mathrm{c}}$ values and is associated with lower fasting and postprandial glucose concentrations and reduced body weight [13]. Consequently, this intestinal hormone has 
been widely proposed as a new therapeutic agent for the treatment of diabetes mellitus $[1,2]$.

Recent studies have shown that the anti-diabetic actions of GLP-1 also include the enhancement of beta cell mass. When given for a prolonged period to normal rodents or animals with impaired glucose tolerance or mild diabetes, GLP-1 or its long-acting ana$\log$, exendin-4 $[14,15]$, increases beta-cell mass $[16$, $17,18,19]$. Moreover, we have shown that daily injection of exendin- 4 prevents the onset of diabetes in obese $d b / d b$ mice with insulin resistance, through a mechanism involving increased insulin release in association with islet neogenesis, as well as enhanced proliferation and decreased apoptosis of the beta cells [20]. Interestingly, GLP-1 treatment concomitantly increased expression of pancreatic protein kinase B (PKB) $\alpha$ (also known as Akt1) in these mice, suggesting that this kinase plays a role in mediating the trophic effects of GLP-1 in the beta cell.

$\mathrm{PKB}$ is a serine-threonine kinase that is activated by phosphatidylinositol-3-kinase (PI3-K) in response to insulin, as well as to various growth factors $[21,22$, $23]$. The three different isoforms of PKB ( $\alpha, \beta$ and $\gamma)$ are widely expressed in mammalian cells, including the pancreatic beta cells, which contain high levels of $\operatorname{PKB} \alpha[24,25]$. Although it is well established that PKB mediates some of the metabolic actions of insulin in peripheral tissues $[22,26]$, activation of PKB also results in the phosphorylation of various downstream protein targets that affect proliferation, cell cycle entry and intracellular apoptotic pathways $[21,22$, 23]. These pleiotropic actions of PKB result in increased cell numbers as well as enhanced cell survival. Consistent with these findings, overexpression of $\mathrm{PKB} \alpha$ in the murine beta cell enhances insulin secretion and reduces glucose concentrations, in association with increased beta-cell mass [27, 28]. PKB $\alpha$ also plays an important role in IGF-1-induced betacell proliferation [29], as well as in IGF-1 and glucose-mediated protection of beta cells from apoptosis [30].

In keeping with PKB's role in beta-cell growth, recent studies have shown an involvement of PI3-K, an upstream activator of PKB, in GLP-1-stimulated betacell proliferation $[31,32,33]$. These findings are consistent with the fact that $\mathrm{PKB}$ phosphorylation is stimulated by GLP-1 in the beta cell [34]. However, it is not clear whether the actions of PKB are essential for GLP-1-stimulated beta-cell proliferation [33]. Similarly, while GLP-1 increases total PKB $\alpha$ levels and reduces apoptosis in rodent beta cells in vivo, as well as in heterologous cells expressing the GLP-1 receptor $[19,20]$, it is not certain that PKB plays an obligatory role in GLP-1-mediated protection of beta cells from apoptosis.

We therefore sought to establish whether the growth and/or survival effects of GLP-1 on the beta cell are dependent on PKB. To do this, we investigat- ed the effects of GLP-1 on proliferation and apoptosis in the presence and absence of PKB, using the pancreatic INS-1 cell line as a model for the beta cell.

\section{Materials and methods}

Cell culture. INS-1 cells were a kind gift from Dr M. Wheeler (Department of Physiology, University of Toronto, Toronto, Ont, Canada). Cells (passage 50-65) were grown in monolayer culture, as described [35]. The medium was RPMI 1640 (Gibco Invitrogen, Burlington, Ont, Canada), containing $10 \mathrm{mmol} / \mathrm{l} \mathrm{HEPES}, 10 \%$ fetal bovine serum, $100 \mathrm{U} / \mathrm{ml}$ penicillin $\mathrm{G}, 100 \mu \mathrm{g} / \mathrm{ml}$ streptomycin, $1 \mathrm{mmol} / \mathrm{l}$ sodium pyruvate, $50 \mu \mathrm{mol} / 12$-mercaptoethanol, and $100 \mu \mathrm{l} / 110 \mathrm{~mol} / 1 \mathrm{NaOH}$, and cells were maintained at $37^{\circ} \mathrm{C}$ in a humidified incubator gassed with $5 \% \mathrm{CO}_{2}$. In studies involving serum-starvation, serum was replaced by $0.1 \%$ BSA in RPMI 1640 without glucose.

Immunoblotting. Cells were grown in $10-\mathrm{cm}$ plates to 80 to $85 \%$ confluence and then treated for various time periods with different doses of GLP-1 or exendin-4 (Bachem California, Torrance, Calif., USA). Some cells were also pre-incubated with wortmannin (100 nmol/l; Sigma Chemical, St. Louis, Mo., USA) for $15 \mathrm{~min}$ before the treatment. Cells were then lysed in buffer containing 1\% Triton X-100 and a mixture of protease and phosphatase inhibitors, as described [20]. The protein content was measured by Bradford assay (Bio-Rad Laboratories, Hercules, Calif., USA) and equal amounts of protein $(50 \mu \mathrm{g})$ were separated by 7 to $10 \%$ sodium dodecyl sulphate-polyacrylamide gel electrophoresis and electrotransferred on to polyvinylidene difluoride filters (Bio-Rad). After probing with rabbit primary antibodies that recognise all three isoforms of phospho-Ser ${ }^{473}$-PKB and total PKB (each at 1:1000; New England BioLabs, Mississauga, Ont, Canada), the immunoreactive bands were visualised with horseradish peroxidase-conjugated sheep anti-rabbit IgG (Cedarlane Laboratories, Hornby, Ont, Canada) using an electrochemiluminescent detection technique (Amersham Pharamacia Biotech, Baie d'Urfe, Que, Canada), as described previously [20].

Cell proliferation assay. INS-1 cells were grown to 80-85\% confluence in 12-well plates, serum-starved for $24 \mathrm{~h}$ and then treated overnight with or without GLP-1 at various concentrations in the presence of $3 \mathrm{mmol} / \mathrm{l}$ glucose. Some cells were also pre-incubated with wortmannin $(100 \mathrm{nmol} / \mathrm{l})$ or genistein (25 $\mu \mathrm{mol} / \mathrm{l}$, Calbiochem, San Diego, Calif., USA) for $20 \mathrm{~h}$ prior before the treatment. DNA synthesis was measured by incubating cells with $37 \mathrm{kBq} / \mathrm{ml}{ }^{3} \mathrm{H}$-methylthymidine (specific activity: $3000 \mathrm{GBq} / \mathrm{mmol}$; Amersham Pharmacia Biotech) for $4 \mathrm{~h}$. Cells were then washed twice in ice-cold PBS and incubated for $30 \mathrm{~min}$ in $1 \mathrm{ml}$ of $5 \%$ trichloroacetic acid on ice to precipitate the DNA. The liquid layer was removed by aspiration and $250 \mu \mathrm{l}$ of $0.1 \mathrm{~mol} / \mathrm{l}$ sodium hydroxide was added to the cells for $30 \mathrm{~min}$ at room temperature. During this time the container was gently shaken. The solubilised material was then transferred to $5 \mathrm{ml}$ of scintillant, and radioactive counts were determined by liquid scintillation counting.

Apoptosis assay. Apoptosis of INS-1 cells was evaluated by 4'6-diamidino-2-phenylindole (DAPI) nuclear staining [36], and using the quantitative colorimetric APO Percentage Apoptosis assay kit (Biocolor, Newtownabbey, Northern Ireland). For the DAPI analysis, cells were seeded on to coverslips in a 12-well plate and allowed to reach 80 to $85 \%$ confluence. Cells were 
then incubated overnight with serum-free media with or without GLP-1 (10 nmol/l). After incubation with staurosporine ( $250 \mathrm{nmol} / \mathrm{l}$, Sigma) for $2 \mathrm{~h}$, the cells were fixed using formaldehyde (3.7\% in PBS) and the nuclei were stained with DAPI $(1 \mu \mathrm{g} / \mathrm{ml}$ in PBS). At least 100 cells were evaluated per treatment $(n=3)$, and apoptotic cells were identified by the typical morphologic criteria of chromatin condensation and fragmentation [36] Images were obtained using an Olympus fluorescent microscope (courtesy of Dr D. Belsham, Department of Physiology, University of Toronto, Toronto, Ont, Canada). For the APO Percentage Apoptosis Assay, INS-1 cells were seeded on a gelatin-coated 96-well plate, grown to $80-85 \%$ confluence, serum-starved for $24 \mathrm{~h}$, and treated overnight in $3 \mathrm{mmol} / \mathrm{l}$ glucose with or without GLP-1 at various concentrations. Some cells were also pre-incubated with wortmannin (100 nmol/l) for $15 \mathrm{~min}$ or genistein $(25 \mu \mathrm{mol} / \mathrm{l})$ for $20 \mathrm{~h}$ before the treatment. Cells were then incubated with staurosporine $(250 \mathrm{nmol} / \mathrm{l})$ for $1 \mathrm{~h}$, with or without wortmannin (100 nmol/l), after which the apoptotic dye was added and the relative changes in colour compared with control cells were measured spectrophotometrically, according to the manufacturer's protocol.

Insulin RIA. Insulin concentrations were measured using an insulin RIA kit (Linco Research, St. Louis, Mo., USA). Cells were grown to $90 \%$ confluence in 12-well plates, and after washing with fresh medium, were pre-treated with glucosefree medium alone (control) or with $100 \mathrm{nmol} / \mathrm{l}$ wortmannin for $30 \mathrm{~min}$, and then treated for $2 \mathrm{~h}$ with medium containing 0 to $5 \mathrm{mmol} / \mathrm{l}$ glucose, $10 \mathrm{nmol} / \mathrm{l} \mathrm{GLP}-1$ and/or $100 \mathrm{nmol} / \mathrm{l}$ wortmannin. The medium was then transferred to Eppendorf tubes, spun at $2000 \mathrm{~g}$ and $4^{\circ} \mathrm{C}$ for $1 \mathrm{~min}$, and the supernatant was collected and placed on ice. Samples were diluted into the assay buffer and assayed for insulin according to the manufacturer's instructions. Preliminary studies showed that the enhancement of glucose-dependent insulin secretion by GLP-1 in the INS-1 cells was maximal at $5 \mathrm{mmol} / \mathrm{l}$ glucose.

$R T-P C R$. Total cellular RNA was extracted from confluent 10$\mathrm{cm}$ plates of INS-1 cells using an RNeasy kit in combination with an 'On-column Dnase Digestion' kit (Qiagen, Mississauga, Ont, Canada). PKB $\alpha$ mRNA transcripts were amplified using the Qiagen OneStep RT-PCR kit with primers [forward: tcaggctcggagattaggta and reverse: gcccaatcggtggtagaact (Invitrogen Life Technologies, Carlsbad, Calif., USA)] designed to generate a $1096 \mathrm{bp}$ fragment [24]. Water was used to replace the template for the negative control. PCR conditions were $94^{\circ} \mathrm{C}$ for $9 \mathrm{~min}$, followed by $94^{\circ} \mathrm{C}$ for $45 \mathrm{~s}, 62^{\circ} \mathrm{C}$ for $45 \mathrm{~s}$ and $72^{\circ} \mathrm{C}$ for $1 \mathrm{~min}$ for 40 cycles. Products were separated on an agarose gel and visualised with ethidium bromide.

Adenoviral vectors and infection. Adenovirus (AdV)-expressing enhanced-green fluorescent protein (GFP) (AdV-GFP, control), wild-type (WT) PKB $\alpha$ (AdV-WT) or kinase-dead (KD) $\mathrm{PKB} \alpha\left(\mathrm{AdV}-\mathrm{KD} ; \mathrm{K}^{179} \mathrm{M}\right)$ have been described [29, 30]. Equivalent amounts of purified virus $\left(0.5-2 \times 10^{7}\right.$ plaque-forming units $/ \mathrm{ml}$ ) were added to $80 \%$ confluent INS- 1 cells for 2 to $4 \mathrm{~h}$, and cells were then washed and incubated for $16 \mathrm{~h}$ in fresh medium. For proliferation assay, cells were seeded in 24-well plates. For apoptosis assay cells were seeded in 6-well plates and then split again in 96-well plates after $16 \mathrm{~h}$ of incubation. Assays were then done as described above.

Statistical analysis. All data are presented as means \pm SEM. Statistical analysis was done by a Student's $t$ test or ANOVA using n-1 custom hypotheses tests as appropriate. Significance was assumed at a $p$ value of less than 0.05 .

\section{Results}

GLP-1 stimulates PI3-K-dependent PKB phosphorylation in INS-1 cells. As shown in Fig. 1a, GLP-1 (10 nmol/l) stimulated PKB phosphorylation by $2.7 \pm 0.7$-fold $(p<0.05)$ within 5 min of adding the peptide to the INS-1 cells. The phosphorylation was sustained for 3 to $4 \mathrm{~h}$, but returned to basal levels by hour 5 of incubation. Similar results were obtained with concentrations of GLP-1 as low as $1 \mathrm{nmol} / \mathrm{l}$. In INS-1 cells pre-treated with wortmannin $(100 \mathrm{nmol} / \mathrm{l})$, a specific pharmacological inhibitor of PI3-K, wortmannin had no noticeable effect on basal PKB activity (Fig. 1b). However, addition of the inhibitor completely abrogated GLP-1-induced PKB phosphorylation, indicating that activation of PKB by GLP-1 occurs in a PI3-K-dependent fashion.

GLP-1 stimulates proliferation of INS-1 cells via a pathway dependent on PI3-K. DNA synthesis using ${ }^{3} \mathrm{H}$-methylthymidine showed (Fig. 2a) that GLP-1 treatment at doses between 1 and $100 \mathrm{nmol} / \mathrm{l}$ stimulated INS-1 cell proliferation in a dose-dependent manner, reaching a maximum of $1.8 \pm 0.5$-fold $(p<0.001)$ of controls at $100 \mathrm{nmol} / \mathrm{l} \mathrm{GLP}-1$. Furthermore, the longacting GLP-1 analog, exendin-4, stimulated proliferation at all concentrations from $10 \mathrm{pmol} / \mathrm{l}$ to $100 \mathrm{nmol} / \mathrm{l}$ $(p<0.05$ to 0.001 ; Fig. 2 b), probably due to decreased degradation. In contrast, although wortmannin $(100 \mathrm{nmol} / \mathrm{l})$ alone did not affect cell proliferation, incubation of INS-1 cells with GLP-1 or exendin-4 in the presence of wortmannin prevented stimulation of cell proliferation, with levels being maintained at basal throughout the incubation period. These findings therefore implicate the PI3-K-PKB pathway in mediating the effects of GLP-1 on INS-1 beta cell proliferation.

GLP-1 inhibits staurosporine-induced apoptosis via a pathway dependent on PI3-K. Treatment of the INS-1 cells with staurosporine for $2 \mathrm{~h}$ increased the number of apoptotic cells from $6.1 \pm 1.8 \%$ to $42.6 \pm 5.2 \%$ of total cells $(p<0.05$, Fig. 3a- $a, b)$. This effect was reduced by GLP-1 pre-treatment to $13.2 \pm 2.2 \% \quad(p<0.05$; Fig. $3 \mathrm{a}-d)$. GLP-1 alone did not alter basal levels of apoptosis (Fig. 3a-c). Consistent with data from the DAPIstaining assay, the quantitative APO Percentage assay, which measures the earliest stages of apoptosis, also showed induction of apoptosis in response to $1 \mathrm{~h}$ of treatment with staurosporine ( $p<0.01$, Fig. $3 \mathrm{~b})$, as well as complete abrogation of this effect by GLP-1 $(p<0.001)$. Furthermore, inhibition of PI3-K with wortmannin abrogated the prevention of apoptosis by GLP-1 $(p<0.001)$. These results show that, like GLP1-induced proliferation, the inhibition of staurosporine-induced apoptosis by GLP-1 is PI3-K dependent. 
a
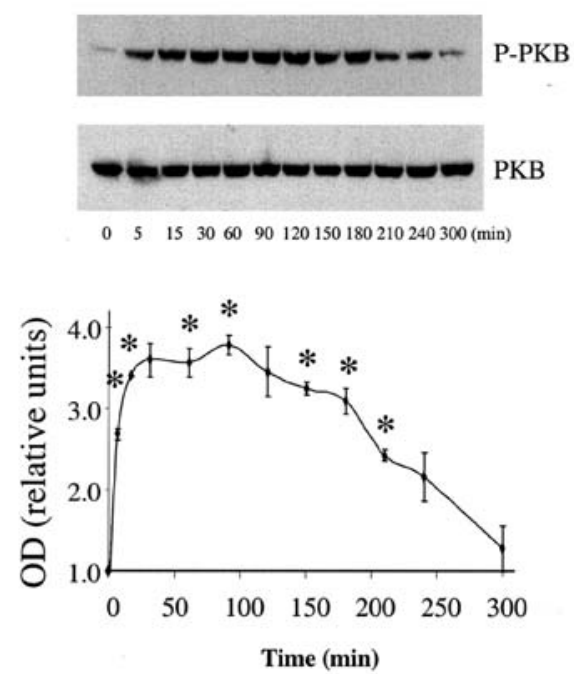

b
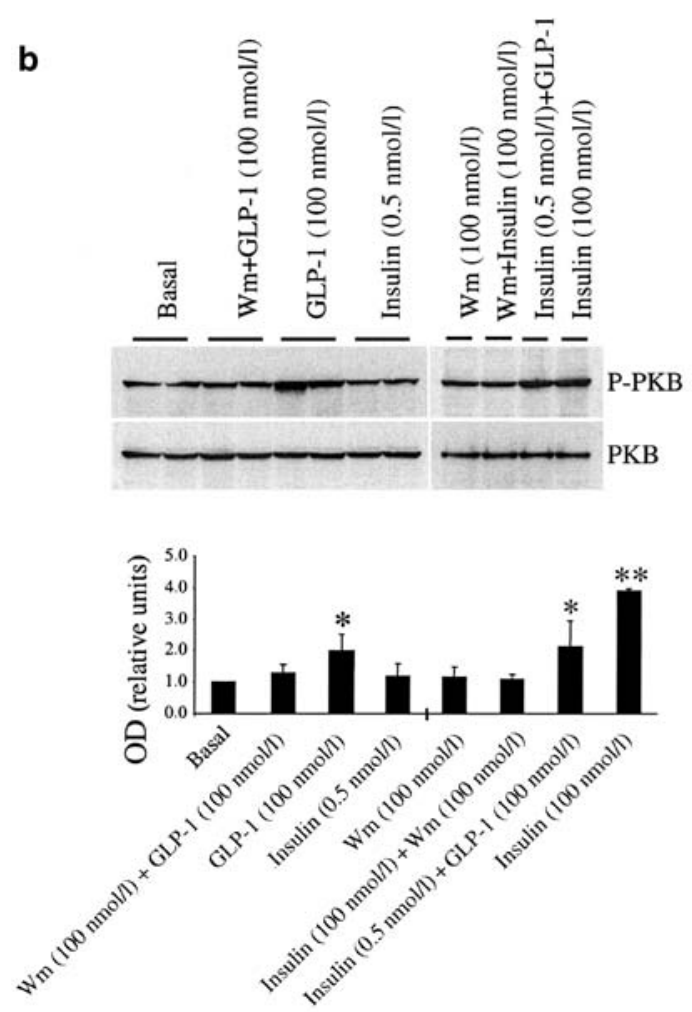

Fig. 1a, b. Effects of glucagon-like peptide-1 on protein kinase B-phosphorylation in pancreatic INS-1 beta cells. INS-1 cells were treated (a) with $10 \mathrm{nmol} / \mathrm{l}$ glucagon-like peptide-1 (GLP1) for up to $5 \mathrm{~h}$, followed by western blot for serine ${ }^{473}$-phosphorylated PKB (P-PKB) and total protein kinase B (PKB). A representative blot and the optical density (OD, normalised to basal levels) from three separate experiments are shown. INS-1 cells (b) were pre-treated with media alone or with $100 \mathrm{nmol} / \mathrm{l}$ wortmannin $(\mathrm{Wm})$, followed by treatment with different agents as indicated for $2 \mathrm{~h}$ and western blot analysis as above. A representative blot and the OD (normalised to basal levels) from four separate experiments are shown. $* p<0.05, * * p<0.01$ a

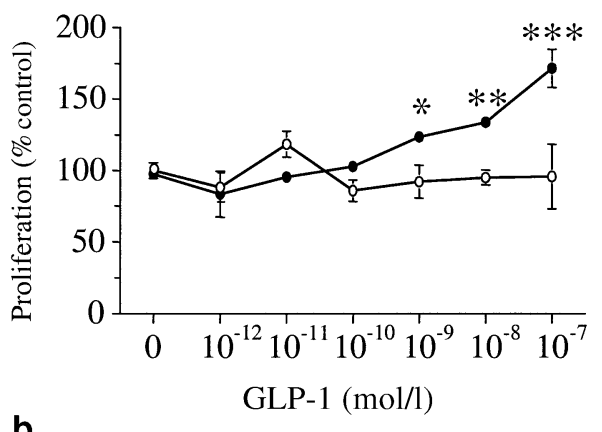

b

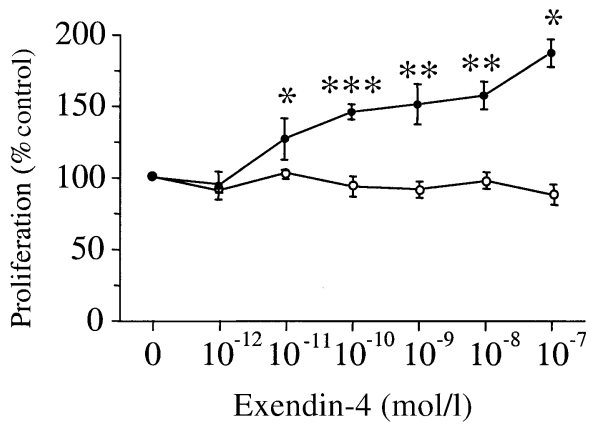

Fig. 2a, b. Effects of glucagon-like peptide-1 on INS-1 cell proliferation. INS-1 cells were treated for $16 \mathrm{~h}$ with media alone (control) or with $10^{-12}$ to $10^{-7} \mathrm{~mol} / \mathrm{l}$ glucagon-like peptide (GLP-1; $n=12)$ (a) or exendin-4 $(n=4)$ (b) in the absence (closed circles) or presence (open circles) of $100 \mathrm{nmol} / \mathrm{l}$ wortmannin. Cell proliferation was measured from the incorporation of ${ }^{3} \mathrm{H}$-thymidine. $* p<0.05, * * p<0.01, * * * p<0.001$ vs control

The effects of GLP-1 on PKB and proliferation are independent of insulin. To determine whether the effects of GLP-1 on PKB phosphorylation, proliferation and apoptosis in the INS-1 cells might be due to autocrine actions of the secreted insulin, we first established that the absolute levels of insulin secreted by the INS-1 cells in response to glucose $(5 \mathrm{mmol} / \mathrm{l})$ plus GLP-1 $(100 \mathrm{nmol} / \mathrm{l})$ was $16.3 \pm 2.9 \mathrm{pmol} / \mathrm{l}$ over a period of $2 \mathrm{~h}$. We then examined whether treatment of the cells with a 30 -fold excess of insulin $(0.5 \mathrm{nmol} / \mathrm{l})$ affected PKB phosphorylation in the INS-1 cells. However, insulin at this concentration did not induce PKB phosphorylation (Fig. 1b). Furthermore, co-incubation of the cells with GLP-1 $(100 \mathrm{nmol} / \mathrm{l})$ plus insulin $(0.5 \mathrm{nmol} / \mathrm{l}) \mathrm{did}$ not increase PKB phosphorylation any more than treatment with GLP-1 alone. As expected, insulin at a supraphysiological concentration $(100 \mathrm{nmol} / \mathrm{l})$ significantly stimulated PKB phosphorylation in a PI3-K-dependent fashion $(p<0.01)$. These results suggested that GLP-1-induced PKB phosphorylation in INS-1 cells occurs through direct effects of GLP-1 signalling, rather than through any autocrine actions of the concomitantly secreted insulin.

To further test this hypothesis, cells were incubated with $100 \mathrm{nmol} / \mathrm{l}$ insulin, alone or with $25 \mu \mathrm{mol} / \mathrm{l}$ genistein, a tyrosine kinase inhibitor, followed by 
a

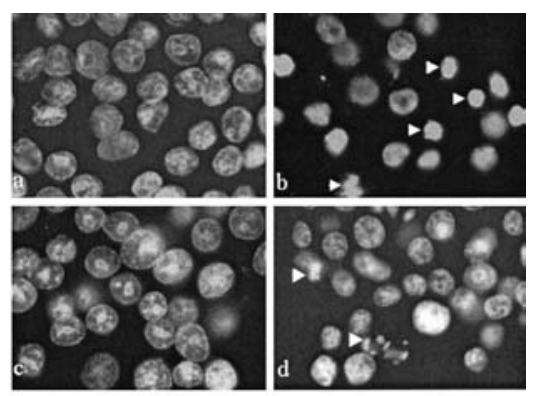

b

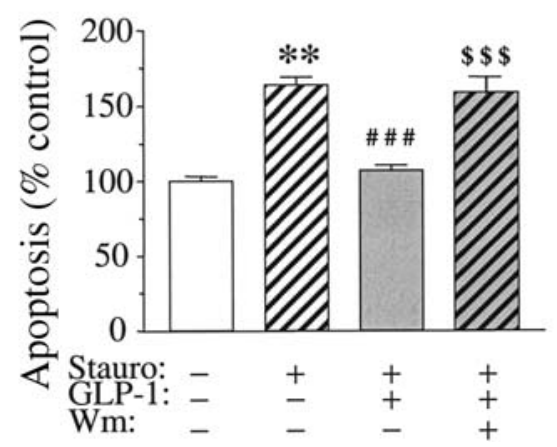

Fig. 3a, b. Effects of glucagon-like peptide on staurosporineinduced apoptosis of INS-1 cells. INS-1 cells (a) were pretreated with media alone or with $10 \mathrm{nmol} / \mathrm{l}$ glucagon-like peptide-1 (GLP-1) for $24 \mathrm{~h}$, and then treated for $2 \mathrm{~h}$ with media or $250 \mathrm{nmol} / 1$ staurosporine (Stauro). Representative photographs $(n=3)$ show 4'-6-diamidino-2-phenylindole nuclear staining in cells pre-treated and treated as follows: $(a)$ media + media, $(b)$ media + Stauro, $(c)$ GLP-1 + media, $(d)$ GLP-1 + Stauro. The arrowheads indicate typical condensed and fragmented nuclei of apoptotic cells. Quantitative APO Percentage Apoptosis assay (b) of INS-1 cells pre-treated with media or $100 \mathrm{nmol} / \mathrm{l}$ GLP-1 and then treated with media, $250 \mathrm{nmol} / 1 \mathrm{Stauro}$ and/or $100 \mathrm{nmol} / 1$ wortmannin $(\mathrm{Wm})$, as indicated $(n=12)$. ** $p<0.01$ vs control cells with no Stauro, ${ }^{\# \#} p<0.001$ vs cells with Stauro but no GLP-1 or Wm, $\$ \$ p<0.001$ vs cells with Stauro and GLP-1 but no Wm

western blot for changes in PKB activation (Fig. 4a). Insulin treatment increased PKB phosphorylation 2.8fold compared with control cells, an effect abrogated by pre-incubation of the cells with genistein (1.3-fold change). In contrast to these inhibitory effects of genistein on insulin action, GLP-1-stimulated INS-1 cell proliferation was not affected by pre-treatment of the cells with genistein (Fig. 4b). Unexpectedly, when the same approach was used to investigate the possible role of tyrosine kinases in GLP-1-mediated protection from apoptosis, genistein alone prevented staurosporine-induced apoptosis, and this effect was not additive with the protective effects of GLP-1 (Fig. 4c). We were therefore unable to determine whether tyrosine kinases play a role in the effects of GLP-1 on apoptosis. Yet taken together, our findings certainly suggest that insulin signalling does not play a major role in mediating GLP-1-induced activation of PKB and GLP-1-induced stimulation of cell growth in the INS-1 beta cell line.
Quantitation of GLP-1-induced insulin secretion in the absence and presence of wortmannin (Fig. 4d) showed that glucose alone $(5 \mathrm{mmol} / \mathrm{l})$ stimulated insulin secretion by the cells (by 2.0 \pm 0.2 -fold, $p<0.001$ ), and this was further increased (to $3.4 \pm 0.8$-fold of control) by adding $100 \mathrm{nmol} / \mathrm{l} \mathrm{GLP}-1$ ( $p<0.001$ vs control, $p<0.01$ vs glucose alone). However, inactivation of PI3-K with wortmannin did not alter these responses. These results suggest that GLP-1-stimulated insulin secretion does not require PI3-K in this cell line. As wortmannin treatment prevented the effects of GLP-1 on INS-1 cell proliferation and apoptosis, but not on insulin secretion, these studies provide further evidence for a lack of involvement of insulin in this pathway.

GLP-1 stimulation of proliferation and inhibition of apoptosis is blocked by ablation of PKB activity. In two separate preparations of total cellular RNA, RTPCR amplified a band corresponding to the expected size for PKB $\alpha$ (Fig. 5a). To functionally ablate PKB, INS-1 cells were infected with AdV-expressing kinase-dead PKB $\alpha$ (AdV-KD). Cells that were infected with GFP (AdV-GFP) and WT PKB $\alpha$ (AdV-WT) were used as controls. Western blot analysis for total PKB showed that expression of PKB in cells infected with AdV-KD and AdV-WTwas 18-fold higher than in AdV-GFP-infected cells (Fig. 5b). Furthermore, PKB activity, as indicated by PKB-phosphorylation, was markedly lower in cells infected with AdV-KD than in AdV-GFP and AdV-WT cells. The AdV-constructs were therefore infected into INS-1 cells followed by analysis of proliferation and apoptosis (Fig. 5c,d). GLP-1 treatment was found to stimulate proliferation $(p<0.001)$ and inhibit staurosporine-induced apoptosis $(p<0.05)$ in cells infected with AdV-GFP, similar to the findings in non-infected cells (Figs. 2, 3, 4). In keeping with PKB's role as a growth and survival factor in beta cells, INS-1 cells infected with AdV-WT had greater basal proliferation $(p<0.001)$ and a complete abrogation of basal staurosporine-induced apoptosis (NS vs controls). The stimulation of proliferation and the inhibition of apoptosis induced by AdV-WT infection were not further modulated by GLP-1, probably due to the extremely high levels of phosphorylated PKB already present in these cells (Fig. 5b). In contrast, infection of the cells with the AdV-KD construct prevented GLP-1-stimulated INS-1 cell proliferation $(p<0.05$ vs AdV-GFP- and AdV-WT-infected cells treated with GLP-1). However, this did not reach control levels, possibly because the construct alone induced a small enhancement of basal proliferation. Furthermore, infection with AdV-KD did not further increase staurosporine-induced apoptosis ( $p=\mathrm{NS}$ vs AdV-GFP cells treated with staurosporine), but did completely abrogate the ability of GLP-1 to protect the cells from apoptosis ( $p<0.01$ vs AdV-GFP- and AdV-WT-infected cells treated with GLP-1). 

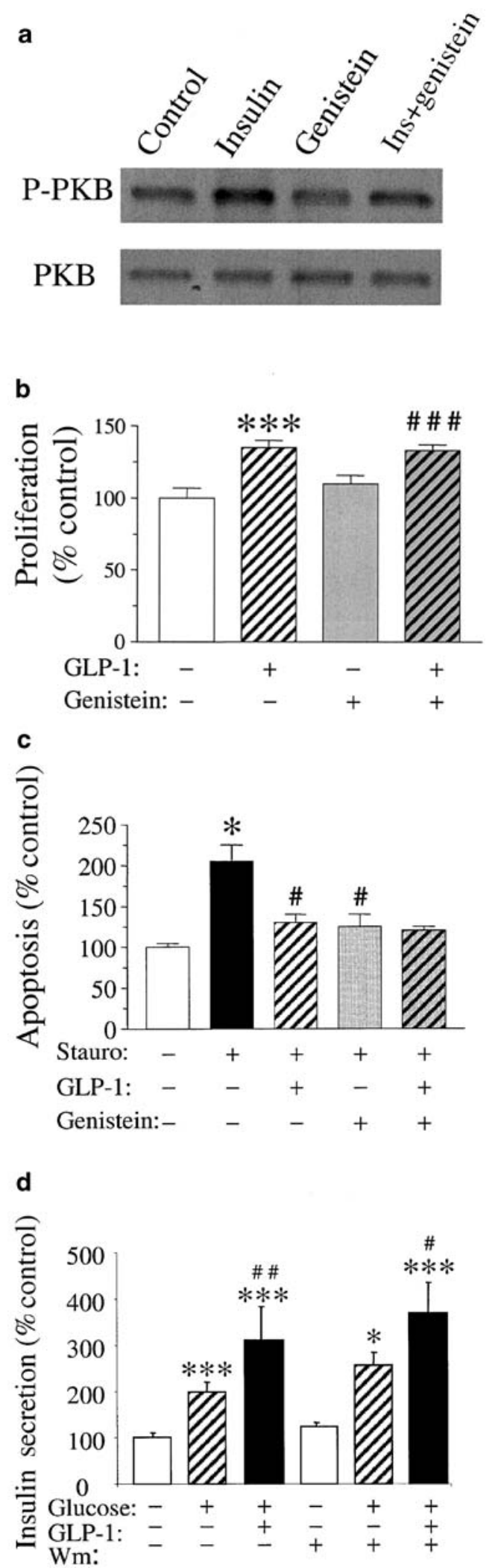

Fig. 4a-d. Role of insulin and tyrosine kinase activity in the effects of glucagon-like peptide-1 on INS-1 cells. INS-1 cells were pre-incubated (a) with media or $25 \mu \mathrm{mol} / 1$ genistein for $24 \mathrm{~h}$, followed by treatment with media or $100 \mathrm{nmol} / \mathrm{l}$ insulin (Ins) for $10 \mathrm{~min}$. Western blots were probed for total protein kinase $\mathrm{B}(\mathrm{PKB})$ and serine ${ }^{473}$-phosphorylated $\mathrm{PKB}$ (P-PKB). INS-1 cells (b) were pre-treated for $20 \mathrm{~h}$ with $10 \mathrm{nmol} / \mathrm{l}$ gluca-

\section{Discussion}

Although originally described as a potent stimulator of glucose-dependent insulin secretion, recent studies $[1,2,3,4,5,6,7,8,10,11,12,13]$ have shown that the intestinal hormone GLP-1 also prevents the onset of diabetes and ameliorates existing diabetes through a mechanism that includes enhancement of beta-cell mass $[16,17,18,19,20]$. Despite limited evidence that GLP-1 can activate PKB [34], and that PKB $\alpha$ overexpression enhances beta-cell mass in vivo [27, 28], no studies have shown whether PKB is essential for GLP-1-induced beta-cell proliferation and/or prevention of apoptosis. In this study, we have shown that the trophic and the survival effects of GLP-1 on INS-1 cells are mediated through PI3-K-PKB, and that these biological actions of GLP-1 are abrogated by functional ablation of PKB using a kinase-dead $\mathrm{PKB} \alpha$ construct.

The role of $\mathrm{PKB} \alpha$ in the regulation of beta-cell growth has been well established [27, 28], and PKB $\alpha$ is expressed in the normal beta cell $[24,25]$. However, INS- 1 cells have been reported to express $\mathrm{PKB} \alpha$ and $\operatorname{PKB} \beta$, but not PKB $\gamma$ [37]. Nonetheless, it is unclear whether PKB $\beta$ plays a role in the modulation of betacell proliferation and/or apoptosis. Indeed, studies on PKB $\beta$ null mice have yielded conflicting results with respect to their islet cell response to the development of insulin resistance, with $129 \mathrm{SV} / \mathrm{C} 57 \mathrm{BL} / 6$ mice showing impaired ability to increase islet mass in response to insulin resistance, and male DBA/1lacJ mice developing overt diabetes with complete loss of beta cells $[38,39]$. Taken with the results of the present study, the available data suggest that $\operatorname{PKB} \alpha$ is more important in the regulation of beta-cell mass than PKB $\beta$.

Previous studies have also shown that mitogen-activated protein kinase (MAPK) and protein kinase $\mathrm{C}-\zeta$

gon-like peptide-1 (GLP-1) in the absence or presence of $25 \mu \mathrm{mol} / 1$ genistein, followed by $4 \mathrm{~h}$ incubation with ${ }^{3} \mathrm{H}$-thymidine to measure proliferation $(n=12)$. $* * * p<0.001$ vs control cells without GLP-1, ${ }^{\# \#} p<0.001$ vs cells treated with genistein but not GLP-1. INS-1 cells (c) were pre-treated for $20 \mathrm{~h}$ with media alone or with $10 \mathrm{nmol} / \mathrm{l} \mathrm{GLP}-1$, followed by treatment with media alone in the absence or presence of $10 \mathrm{nmol} / \mathrm{l} \mathrm{GLP}-1$ and $25 \mu \mathrm{mol} / \mathrm{l}$ genistein for $20 \mathrm{~h}$. Cells were then treated with $250 \mathrm{nmol} / \mathrm{l}$ staurosporine (Stauro) for $1 \mathrm{~h}$ followed by Apo Percentage assay for apoptosis. ${ }^{*} p<0.05$ vs control cells with no Stauro, \# $p<0.05$ vs cells treated with Stauro alone $(n=12)$. INS-1 cells $(\mathbf{d})$ were pre-treated with glucose-free media alone or with $100 \mathrm{nmol} / \mathrm{l}$ wortmannin $(\mathrm{Wm})$, followed by treatment for $2 \mathrm{~h}$ with glucose-free media or media containing $5 \mathrm{mmol} / \mathrm{l}$ glucose, $100 \mathrm{nmol} / \mathrm{l}$ GLP-1, and/or $100 \mathrm{nmol} / \mathrm{l} \mathrm{Wm}$. RIA was used to measure the concentrations of insulin in the media $(n=12)$. Basal secretion was $5.1 \pm 0.7 \mathrm{pmol} / \mathrm{l}$ over $2 \mathrm{~h}$. $* p<0.05$ and $* * * p<0.001$ vs the same group of cells in glucose-free media; \# $p<0.05$ and \#\# $p<0.01$ vs the same group of cells treated with glucose but not GLP-1 
a

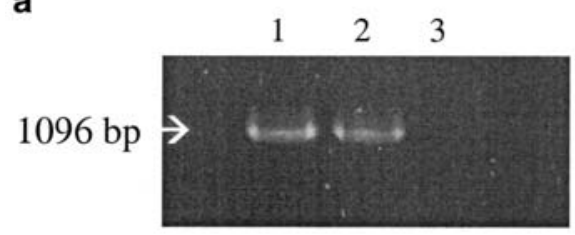

b

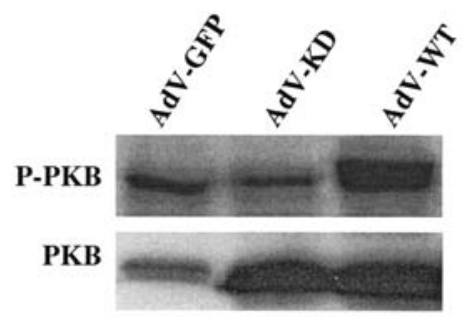

C

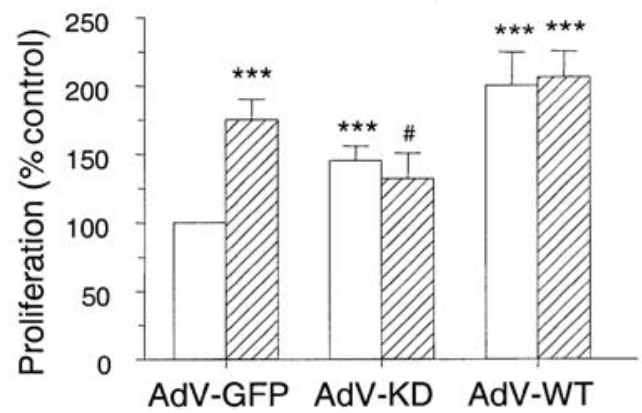

d

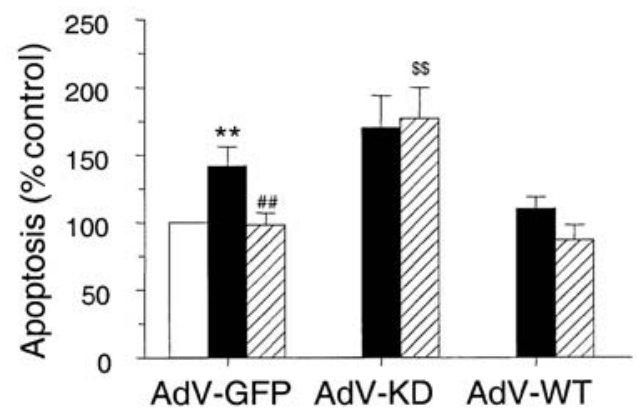

Fig. 5a-d. Role of protein kinase B in glucagon-like peptide1 -induced stimulation of proliferation and inhibition of apoptosis. RT-PCR (a) of INS-1 cells (lanes 1-2) for protein kinase B (PKB) $\alpha$. Lane 3 shows the negative control. The expected size of $\mathrm{PKB} \alpha$ is indicated by the arrow. INS- 1 cells were infected (b) for 2 to $4 \mathrm{~h}$ with 0.5 to $2 \times 10^{7} \mathrm{pfu} / \mathrm{ml}$ of AdV-GFP, AdV$\mathrm{KD}$ or AdV-WT and then incubated in media alone for a further $16 \mathrm{~h}$, followed by western blot for serine ${ }^{473}$-phosphorylated PKB (P-PKB) and total PKB. INS-1 cells (c) were infected as above, and then treated for $20 \mathrm{~h}$ with media alone (open bars) or with $10 \mathrm{nmol} / \mathrm{l}$ glucagon-like peptide 1 (GLP-1; hatched bars), followed by incubation with ${ }^{3} \mathrm{H}$-thymidine for $4 \mathrm{~h}$ to measure proliferation $(n=10-16)$. $* * * p<0.001 \mathrm{vs} \mathrm{AdV-}$ GFP-infected cells treated with media alone, ${ }^{\#} p<0.05$ vs AdVGFP- and AdV-WT-infected cells treated with GLP-1. INS-1 cells (d) were infected as above. They were then pre-treated for $20 \mathrm{~h}$ with media alone (open bar) or with $10 \mathrm{nmol} / \mathrm{l} \mathrm{GLP}-1$ (hatched bars), and treated for $1 \mathrm{~h}$ with media alone or with $250 \mathrm{nmol} / 1$ staurosporine (closed and hatched bars), followed play a role in GLP-1-induced proliferation of INS-1 $(832 / 13)$ cells $[32,33]$. Furthermore, studies on beta cell proliferative response to IGF-1 have indicated that there is a balance between these pathways in INS-1 cells, such that overexpression of $\mathrm{PKB} \alpha$ can lead to down-regulation of MAPK [29]. Similar studies on the beta cell response to another growth factor, glucose-dependent insulinotropic peptide (GIP), have also indicated that these pathways are linked in INS-1 cells [37, 40]. The present findings suggest that MAPK and protein kinase $\mathrm{C}-\zeta$ could act downstream of PKB in INS-1 cells, as PKB seems to be both necessary and sufficient to modulate the actions of GLP-1 on beta-cell growth and survival.

Overexpression of kinase-dead PKB $\alpha$ was used in this study to demonstrate the essential role of PKB in mediating GLP-1-stimulated proliferation and protection from apoptosis. A similar approach was used to show that $\mathrm{PKB}$ is important in the proliferative response of INS-1 cells to IGF-1 [29], as well as in IGF1 -induced protection of INS- 1 cells from fatty acid-induced apoptosis [30]. In contrast, $\mathrm{p} 70^{\mathrm{s} 6 \mathrm{~K}}$, but not $\mathrm{PKB}$, seems to be involved in the proliferative effects of glucose on these cells [29]. The signalling pathways downstream of PKB that are activated by GLP-1 treatment of the INS-1 cells have not been elucidated. However, glycogen synthase kinase- $3 \alpha / \beta$ (GSK3 $\alpha / \beta)$, FoxO1 and p53 have been implicated in IGF-1-induced cell growth and survival, whereas mammalian target of rapamycin is thought to play a role in glucose-stimulated proliferation [29, 30]. Furthermore, small changes in the activities of GSK3 $\alpha / \beta$ and FoxO1 have been noted in INS-1 cells treated with GIP [37].

Unlike many classic growth factors, including IGF-1, that stimulate cell growth through receptortyrosine kinase-mediated activation of PKB [29], the GLP-1 receptor is a member of the 7-transmembranespanning, G protein-coupled receptor (GPCR) superfamily [41]. GLP-1 stimulates insulin secretion through modulation of the cAMP-PKA pathway [5, 42], and in keeping with these findings, wortmannin treatment did not affect GLP-1-stimulated insulin secretion by the INS-1 cells. However, there is growing evidence that a number of hormones that signal through GPCRs can also activate cell growth and survival pathways, including GLP-1 (present study), GIP, the GLP-1-related intestinal hormone GLP-2 and parathyroid hormone-related protein (PTHrP). Like GLP-1, GIP enhances proliferation and prevents apop-

by Apo Percentage Apoptosis assay $(n=14-19)$. ** $p<0.01$ vs AdV-GFP-infected cells treated with media alone, \#\# $p<0.01$ vs AdV-GFP-infected cells treated with staurosporine alone, $\$ \$ p<0.01$ vs AdV-GFP- and AdV-WT-infected cells treated with GLP-1. AdV, adenovirus; GFP, enhanced green fluorescent protein; KD, kinase-dead; WT, wild-type 
tosis in INS-1 cells, in association with activation of PKB $\alpha$, PKB $\beta$ and MAPK [37, 40, 43]. However, unlike the responses to GLP-1, wortmannin does not prevent GIP-induced beta-cell growth or survival [40]. Similarly, GLP-1 treatment prevents chemically-induced apoptosis in association with enhanced total PKB levels in baby hamster kidney fibroblasts transfected with the GLP-1 receptor [19]. However, in the same cells transfected with the GLP-2 receptor, inhibition of apoptosis by GLP-2 appears to be PKB-independent [44]. Finally, PTHrP exerts both pro- and anti-apoptotic effects on osteoblasts, with the direction of the effect dependent on cell number [45]. However, the pro-apoptotic effects appear to be mediated through inhibition of PKB activation, whereas the anti-apoptotic actions of PTHrP are independent of PKB. Thus, modulation of cell growth and survival, even within a single model, appear to be regulated by distinct pathways that are differentially coupled to unique GPCRs and that could be influenced by various other inputs. The exact mechanism(s) by which GPCRs couple to the PI3-K-PKB pathway are unclear, but could involve specific isoforms of PI3-K [46] or cAMP-regulated guanine nucleotide exchange factor, a protein known to stimulate PKB [47] and that is activated by GLP-1 in INS-1 cells [48].

In our study, inhibition of tyrosine kinase activity with genistein did not affect basal proliferation or the growth response to GLP-1 in INS-1 cells. These findings differ slightly from another study [40], in which basal but not GIP-stimulated proliferation was inhibited by genistein. In marked contrast to this and our present study, it has also recently been reported that the proliferative effects of GLP-1 are mediated through transactivation of the epidermal growth factor receptor tyrosine kinase in the INS-1(832/13) subclone of INS-1 cells [33]. However, INS-1(832/13) cells overexpress the human proinsulin gene [49], so indirect effects mediated through high levels of insulin secretion cannot be discounted in this model. Finally, genistein treatment reduced chemically-induced apoptosis in the INS-1 cells used in our study, preventing assessment of the role of tyrosine kinases in GLP-1-mediated protection from apoptosis, while genistein treatment of INS-1 cells in the other study [40] did not alter basal but did prevent the effects of GIP on apoptosis. These findings further suggest that the pathways regulating proliferation and apoptosis in the beta cell are probably both cell line- and hormone-specific. In keeping with this notion, the trophic effects of GLP-1 in vivo appear to differ between rodent models. For example, GLP-1 increased beta-cell mass when injected into C57B1/6 and $d b / d b$ mice $[18,20]$, but overexpression of exendin- 4 in C57BL/6×SJL mice had no effect on islet size [50]. Moreover, antagonist-mediated prevention of GLP-1 action does not affect islet mass in Balb/c mice, although islet growth and topography are abnormal in GLP-1 receptor null CD1 mice [51, 52].
In our study activation of PKB by GLP-1 occurred rapidly, reaching maximum values within $15 \mathrm{~min}$ and remaining higher for 3 to $4 \mathrm{~h}$. This rapid but prolonged induction of PKB is similar to the time courses observed for GIP- and IGF-1-induced PKB phosphorylation in INS-1 cells [29, 37]. However, the time course of growth factor-induced PKB activation differs markedly from that in cells in which PKB modulates metabolic activity rather than growth. An example of one such pathway is the regulation by insulin of glucose transport in skeletal muscle cells. PKB activation in these cells occurs very rapidly $(<5 \mathrm{~min})$, but also returns to basal levels within a short time frame (approximately $30 \mathrm{~min}$ ) [26]. These findings are consistent with the need for acute cellular responses to changing metabolic conditions rather than more chronic responses under conditions that lead to altered cellular growth. In keeping with PKB's role in the chronic growth effects of GLP-1 in vivo, we have observed increased levels of total [20] and phosphorylated PKB, in association with enhancement of beta cell mass, in the pancreas of $d b / d b$ mice treated with exendin-4 for 10 days.

In summary, the results show the essential role of PKB in mediating the proliferative and the anti-apoptotic effects of GLP-1 in INS-1 cells. These findings provide a possible explanation of the proven ability of GLP-1 to increase proliferation and decrease apoptosis of rodent beta cells in vivo, leading to enhanced islet mass and improved beta-cell function. These findings could be of clinical significance, as GLP-1 is currently in clinical trials for the treatment of hyperglycaemia in patients with Type 2 diabetes.

Acknowledgements. This work was supported by an operating grant from the Canadian Diabetes Association to P.L. Brubaker. Q. Wang is the recipient of a Canadian Diabetes Association Scholarship and is also supported by the Canadian Institute of Health Research Senior Research Fellowship Program (Phase II). L. Li is supported by a post-doctoral fellowship from the Canadian Diabetes Association, and P.L. Brubaker is supported by the Canada Research Chairs Program. The authors are grateful to Drs P. MacDonald and M.B. Wheeler (Department of Physiology, University of Toronto) for providing the INS-1 cells and for assistance with the adenovirus studies, and to Ms L. Chow and Ms A. Tropea for technical assistance.

\section{References}

1. Drucker DJ (2002) Biological actions and therapeutic potential of the glucagon-like peptides. Gastroenterology 122:531-544

2. Nauck MA, Holst JJ, Willms B, Schmiegel W (1997) Glucagon-like peptide 1 (GLP-1) as a new therapeutic approach for Type 2 diabetes. Exp Clin Endocrinol Diabetes 105:187-195

3. Nauck MA, Wollschlager D, Werner J et al. (1996) Effects of subcutaneous glucagon-like peptide 1 (GLP-1 [7-36 amide]) in patients with NIDDM. Diabetologia 39:15461553 
4. Ritzel R, Orskov C, Holst JJ, Nauck MA (1995) Pharmacokinetic, insulinotropic, and glucagonostatic properties of GLP-1 [7-36 amide] after subcutaneous injection in healthy volunteers. Dose-response-relationships. Diabetologia 38:720-725

5. Holz GG 4th, Kuhtreiber WM, Habener JF (1993) Pancreatic beta-cells are rendered glucose-competent by the insulinotropic hormone glucagon-like peptide-1(7-37). Nature 361:362-365

6. Komatsu R, Matsuyama T, Namba M et al. (1989) Glucagonostatic and insulinotropic action of glucagon-like peptide I-(7-36)-amide. Diabetes 38:902-905

7. Willms B, Werner J, Holst JJ, Orskov C, Creutzfeldt W, Nauck MA (1996) Gastric emptying, glucose responses, and insulin secretion after a liquid test meal: effects of exogenous glucagon-like peptide-1 (GLP-1)-(7-36) amide in type 2 (noninsulin-dependent) diabetic patients. J Clin Endocrinol Metab 81:327-332

8. Schirra J, Kuwert P, Wank U et al. (1997) Differential effects of subcutaneous GLP-1 on gastric emptying, antroduodenal motility, and pancreatic function in men. Proc Assoc Am Physicians 109:84-97

9. Tang-Christensen M, Larsen PJ, Thulesen J, Romer J, Vrang N (2000) The proglucagon-derived peptide, glucagon-like peptide-2, is a neurotransmitter involved in the regulation of food intake. Nat Med 6:802-807

10. Toft-Nielsen MB, Madsbad S, Holst JJ (1999) Continuous subcutaneous infusion of glucagon-like peptide 1 lowers plasma glucose and reduces appetite in type 2 diabetic patients. Diabetes Care 22:1137-1143

11. Sandhu H, Wiesenthal S, MacDonald PE et al. (1999) Glucagon-like peptide-1 increases insulin sensitivity in depancreatized dogs. Diabetes 48:1045-1053

12. Prigeon RL, Quddusi S, Paty B, D'Alessio DA (2003) Suppression of glucose production by GLP-1 independent of islet hormones: a novel extrapancreatic effect. Am J Physiol Endocrinol Metab 285:E701-E707

13. Zander M, Madsbad S, Madsen JL, Holst JJ (2002) Effect of 6-week course of glucagon-like peptide 1 on glycaemic control, insulin sensitivity, and beta-cell function in type 2 diabetes: a parallel-group study. Lancet 359:824-830

14. Thum A, Hupe-Sodmann K, Goke R, Voigt K, Goke B, McGregor GP (2002) Endoproteolysis by isolated membrane peptidases reveal metabolic stability of glucagon-like peptide-1 analogs, exendins-3 and -4. Exp Clin Endocrinol Diabetes 110:113-118

15. Goke R, Fehmann HC, Linn T et al. (1993) Exendin-4 is a high potency agonist and truncated exendin-(9-39)-amide an antagonist at the glucagon-like peptide 1-(7-36)-amide receptor of insulin-secreting beta-cells. J Biol Chem 268:19650-19655

16. Edvell A, Lindstrom P (1999) Initiation of increased pancreatic islet growth in young normoglycemic mice (Umea $+/$ ?). Endocrinology 140:778-783

17. Xu G, Stoffers DA, Habener JF, Bonner-Weir S (1999) Exendin-4 stimulates both beta-cell replication and neogenesis, resulting in increased beta-cell mass and improved glucose tolerance in diabetic rats. Diabetes 48:2270-2276

18. Stoffers DA, Kieffer TJ, Hussain MA et al. (2000) Insulinotropic glucagon-like peptide 1 agonists stimulate expression of homeodomain protein IDX-1 and increase islet size in mouse pancreas. Diabetes 49:741-748

19. Li Y, Hansotia T, Yusta B, Ris F, Halban PA, Drucker DJ (2003) Glucagon-like peptide-1 receptor signaling modulates beta cell apoptosis. J Biol Chem 278:471-478

20. Wang Q, Brubaker PL (2002) Glucagon-like peptide-1 treatment delays the onset of diabetes in 8 week-old $\mathrm{db} / \mathrm{db}$ mice. Diabetologia 45:1263-1273
21. Kandel ES, Hay N (1999) The regulation and activities of the multifunctional serine/threonine kinase Akt/PKB. Exp Cell Res 253:210-229

22. Hajduch E, Litherland GJ, Hundal HS (2001) Protein kinase $\mathrm{B}(\mathrm{PKB} / \mathrm{Akt})$ - a key regulator of glucose transport? FEBS Lett 492:199-203

23. Scheid MP, Woodgett JR (2001) PKB/AKT: functional insights from genetic models. Nat Rev Mol Cell Biol 2:760768

24. Holst LS, Mulder H, Manganiella V et al. (1998) Protein kinase $\mathrm{B}$ is expressed in pancreatic beta cells and activated upon stimulation with insulin-like growth factor I. Biochem Biophys Res Commun 250:181-186

25. Aikin R, Rosenberg L, Maysinger D (2000) Phosphatidylinositol 3-kinase signaling to Akt mediates survival in isolated canine islets of Langerhans. Biochem Biophys Res Commun 277:455-461

26. Sherwood DJ, Dufresne SD, Markuns JF et al. (1999) Differential regulation of MAP kinase, p70(S6K), and Akt by contraction and insulin in rat skeletal muscle. Am J Physiol Endocrinol Metab 276:E870-E878

27. Bernal-Mizrachi E, Wen W, Stahlhut S, Welling CM, Permutt MA (2001) Islet beta cell expression of constitutively active Akt1/PKB alpha induces striking hypertrophy, hyperplasia, and hyperinsulinemia. J Clin Invest 108:16311638

28. Tuttle RL, Gill NS, Pugh W et al. (2001) Regulation of pancreatic beta-cell growth and survival by the serine/threonine protein kinase Akt1/PKBalpha. Nat Med 7:1133-1137

29. Dickson LM, Lingohr MK, McCuaig J et al. (2001) Differential activation of protein kinase B and p70(S6)K by glucose and insulin-like growth factor 1 in pancreatic betacells (INS-1). J Biol Chem 276:21110-21120

30. Wrede CE, Dickson LM, Lingohr MK, Briaud I, Rhodes CJ (2002) Protein kinase B/Akt prevents fatty acid-induced apoptosis in pancreatic beta-cells (INS-1). J Biol Chem 277:49676-49684

31. Buteau J, Roduit R, Susini S, Prentki M (1999) Glucagonlike peptide-1 promotes DNA synthesis, activates phosphatidylinositol 3-kinase and increases transcription factor pancreatic and duodenal homeobox gene 1 (PDX-1) DNA binding activity in beta (INS-1)-cells. Diabetologia 42:856-864

32. Buteau J, Foisy S, Rhodes CJ, Carpenter L, Biden TJ, Prentki M (2001) Protein kinase Czeta activation mediates glucagon-like peptide-1-induced pancreatic beta-cell proliferation. Diabetes 50:2237-2243

33. Buteau J, Foisy S, Joly E, Prentki M (2003) Glucagon-like peptide 1 induces pancreatic beta-cell proliferation via transactivation of the epidermal growth factor receptor. Diabetes 52:124-132

34. Trumper K, Trumper A, Trusheim H, Arnold R, Goke B, Horsch D (2000) Integrative mitogenic role of protein kinase B/Akt in beta-cells. Ann NY Acad Sci 921:242-250

35. Asfari M, Janjic D, Meda P, Li G, Halban PA, Wollheim CB (1992) Establishment of 2-mercaptoethanol-dependent differentiated insulin- secreting cell lines. Endocrinology 130:167-178

36. Godard T, Deslandes E, Lebailly P et al. (1999) Comet assay and DNA flow cytometry analysis of staurosporine-induced apoptosis. Cytometry 36:117-122

37. Trumper A, Trumper K, Trusheim H, Arnold R, Goke B, Horsch D (2001) Glucose-dependent insulinotropic polypeptide is a growth factor for beta (INS-1) cells by pleiotropic signaling. Mol Endocrinol 15:1559-1570

38. Cho H, Mu J, Kim JK et al. (2001) Insulin resistance and a diabetes mellitus-like syndrome in mice lacking the protein kinase Akt2 (PKB beta). Science 292:1728-1731 
39. Garofalo RS, Orena SJ, Rafidi K et al. (2003) Severe diabetes, age-dependent loss of adipose tissue, and mild growth deficiency in mice lacking Akt2/PKB beta. J Clin Invest 112:197-208

40. Trumper A, Trumper K, Horsch D (2002) Mechanisms of mitogenic and anti-apoptotic signaling by glucose-dependent insulinotropic polypeptide in beta(INS-1)-cells. J Endocrinol 174:233-246

41. Brubaker PL, Drucker DJ (2002) Structure-function of the glucagon receptor family of $\mathrm{G}$ protein-coupled receptors: the glucagon, GIP, GLP-1 and GLP-2 receptors. Receptors Channels 8:179-188

42. Xiao Q, Giguere J, Parisien M et al. (2001) Biological activities of glucagon-like peptide-1 analogues in vitro and in vivo. Biochemistry 40:2860-2869

43. Ehses JA, Pelech SL, Pederson RA, McIntosh CH (2002) Glucose-dependent insulinotropic polypeptide activates the Raf-Mek1/2- ERK1/2 module via a cyclic AMP/cAMPdependent protein kinase/Rap1-mediated pathway. J Biol Chem 277:37088-37097

44. Yusta B, Estall J, Drucker DJ (2002) Glucagon-like peptide-2 receptor activation engages Bad and glucagon synthase kinase- 3 in a protein kinase A-dependent manner and prevents apoptosis following inhibition of phosphatidylinositol 3-kinase. J Biol Chem 277:24896-24906

45. Chen HL, Demiralp B, Schneider A et al. (2002) Parathyroid hormone and parathyroid hormone-related protein exert both pro- and anti-apoptotic effects in mesenchymal cells. J Biol Chem 277:19374-19381
46. Sasaki T, Irie-Sasaki J, Jones RG et al. (2000) Function of PI3Kgamma in thymocyte development, T cell activation, and neutrophil migration. Science 287:1040-1046

47. Mei FC, Qiao J, Tsygankova OM, Meinkoth JL, Quilliam LA, Cheng X (2002) Differential signaling of cyclic AMP: opposing effects of exchange protein directly activated by cyclic AMP and cAMP-dependent protein kinase on protein kinase B activation. J Biol Chem 277:11497-11504

48. Kang G, Chepurny OG, Holz GG (2001) cAMP-regulated guanine nucleotide exchange factor II (Epac2) mediates $\mathrm{Ca} 2+$-induced $\mathrm{Ca} 2+$ release in INS-1 pancreatic beta-cells. J Physiol 536:375-385

49. Hohmeier HE, Mulder H, Chen G, Henkel-Rieger R, Prentki M, Newgard CB (2000) Isolation of INS-1-derived cell lines with robust ATP-sensitive $\mathrm{K}+$ channel-dependent and -independent glucose-stimulated insulin secretion. Diabetes 49:424-430

50. Baggio L, Adatia FA, Bock T, Brubaker PL, Drucker DJ (2000) Sustained expression of exendin-4 does not perturb glucose homeostasis, beta-cell mass, or food intake in metallothionein-preproexendin transgenic mice. J Biol Chem 275:34471-34477

51. Ling Z, Wu D, Zambre Y et al. (2001) Glucagon-like peptide 1 receptor signaling influences topography of islet cells in mice. Virchows Arch 438:382-387

52. De Leon DD, Deng S, Madani R, Ahima RS, Drucker DJ, Stoffers DA (2003) Role of endogenous glucagon-like peptide-1 in islet regeneration after partial pancreatectomy. Diabetes 52:365-371 